\title{
LEACHING STUDIES OF SCHWERTMANNITE-RICH PRECIPITATES FROM THE ANIMAS RIVER HEADWATERS, COLORADO AND BOULDER RIVER HEADWATERS, MONTANA
}

\author{
by \\ George Desborough ${ }^{1}$, Reinhard Leinz', Stephen Sutley ${ }^{1}$, Paul Briggs ${ }^{1}$, Greg A.Swayze ${ }^{1}$, \\ Kathy Smith ${ }^{1}$, and George Breit ${ }^{1}$
}

Open-File Report 00-004

2000

This report is preliminary and has not been reviewed for conformity with U.S. Geological Survey editorial standards or with the North American Stratigraphic Code. Any use of trade, product, or firm names is for descriptive purposes only and does not imply endorsement by the U.S. Government.

\section{U.S. Department of the Interior}

\section{U.S. Geological Survey}

${ }^{1}$ U.S. Geological Survey, Denver, Colorado 
Abstract

Introduction and Background

Current Study

Deionized water leachates of a schwertmannite-rich sample from Cement Creek near

Silverton, Colorado.

Amorphous orange precipitates formed in less acidic water

Summary....

References

Appendix I. National Atmospheric Deposition Program (NADP) data for monitoring sites near the Colorado study area and the Montana study area for 1997

Appendix II. Major and minor cations and sulfate in nine leachates of A97D16X, A97D16Y, and A97D16Z.

Appendix III. Concentrations of sulfate and hydrogen ion in leachates of X, Y, and $Z$ on a per gram

Basis

\section{FIGURES}

Figure 1. Location of sample sites in Cement and Mineral Creeks near Silverton, Colorado. An Fe bog extends from A98D17 upstream to the junction of Prospect Gulch with Cement Creek.

Figure 2. Concentrations of some metals and sulfate in water at four sites along Cement Creek

Figure 3. Relation of dissolved sulfate and $\mathrm{H}^{+}$in leachates of three schwertmannite-rich samples from site A98D16 along Cement Creek.

\section{TABLES}

Table 1. Locations of schwertmannite-rich orange deposits in Colorado and Montana with pH of stream water, other minerals, date collected, and concentrations of $\mathrm{Cu}, \mathrm{Zn}, \mathrm{As}$, and $\mathrm{Pb}$ in schwertmannite-rich material ......

Table 2. Concentrations of cations and sulfate in water samples and $\mathrm{pH}$ of waterfrom four sites along Cement Creek collected at the time the A98D-series schwertmannite-rich samples were obtained.....

Table 3. Chemical compositions of three untreated A97D16 schwertmannite-rich samples and three splits-X, Y, and Z-each leached nine times for $24 \mathrm{~h}$

Table 4. Sum of total mass of dissolved $\mathrm{Fe}, \mathrm{Cu}, \mathrm{Zn}, \mathrm{Pb}$, and sulfate in nine serial leaches of one gram of schwertmannite-rich material.

Table 5. Locations, water $\mathrm{pH}$, collection date, and concentrations of $\mathrm{Cu}, \mathrm{Zn}$, and $\mathrm{Pb}$ in two amorphous $\mathrm{Fe}$ rich orange precipitates in the Cement Creek drainage in the Animas River headwaters near Silverton, Colorado

Table 6. Concentrations of selected elements in a primary schwertmannite leachate and the subsequent leachates of two Fe-rich orange precipitates. 


\begin{abstract}
$\mathrm{X}$-ray diffraction (XRD) analysis and reflectance spectroscopy show that orange-colored precipitates that have accumulated in pH 3.5 to 4.0 headwaters of the Animas River in Colorado and the Boulder River in Montana may consist chiefly of schwertmannite $\left[\mathrm{Fe}_{16} \mathrm{O}_{16}(\mathrm{OH})_{9.6}\left(\mathrm{SO}_{4}\right)_{3.2} \cdot 10 \mathrm{H} 2 \mathrm{O}\right]$. This mineral is present in streams of coal-mining areas in Ohio but has not been previously reported to occur in the western U.S. These precipitates, which may be accompanied by other solid phases including silicates, goethite, and XRD undetectable amorphous material, were often called "ochre- or orange-colored colloids" by other investigators who noted they may contain significant concentrations of $\mathrm{Cu}, \mathrm{Cd}, \mathrm{Pb}, \mathrm{Zn}$, and As. The toxicity of these metals to aquatic organisms was recognized in prior studies as were the potentially harmful effects of colloidal Fe-hydroxides accumulating on the gills of salmonids (trout).

Passive serial leaching tests in the laboratory showed that as little as one gram of schwertmannite-rich precipitate generated enough acid to lower the $\mathrm{pH}$ of two liters of deionized water from 5 to 3.5 in an initial leach of 24 hours. Acid generation continued for eight successive leaches and was accompanied by the release of metals and sulfate into solution. Comparable results were obtained when the same amount of precipitate was serially leached with 3- and 4-liter quantities of water. The results indicate that 43 to 48 percent of schwertmannite was removed from the precipitates by total water volumes of 18,27 , and 36 liters in the three sets of leaches. Field test along $3.5 \mathrm{~km}$ of Cement Creek in the Animas River basin in October of 1998, a time of low flow, indicate the schwertmannite-rich precipitates accumulated at a rate equivalent to $370 \mathrm{~kg} \mathrm{day}^{-1}$ of $\mathrm{Fe}$. The results of this study infer that acid formation during subsequent leaching of the accumulated precipitates during spring and summer snow-melt runoff may pose another problem to the aqueous environment.
\end{abstract}

INTRODUCTION AND BACKGROUND

Prior to this study we found no published reports of schwertmannite in the Rocky Mountain region of the western U.S. However, J. M. Bigham (Pers. Comm., 1999) identified schwertmannite in samples from St. Kevin Gulch, near Leadville, Colorado. Runnells and Rampe (1989), Ranville and others (1989), Kimball and others (1995), and Church and others (1997) described "ochre-colored colloids" in suspension and as "precipitates" coating rocks in both the Arkansas River and Animas River headwaters of Colorado but the phase was not identified. These investigators have referred to the orange precipitates as "hydrous iron-oxide colloids", although some may be schwertmannite because the $\mathrm{pH}$ of some of the drainages is favorable for schwertmannite precipitation. High magnification $(>50,000 \mathrm{X})$ transmission electron microscopy is necessary to identify the morphology of schwertmannite crystals (Bigham and others, 1990, 1994). Schwertmannite also has a unique spectral reflectance signature. In the original description of schwertmannite, the empirical formula was given as $\mathrm{Fe}_{16} \mathrm{O}_{16}(\mathrm{OH})_{9.6}\left(\mathrm{SO}_{4}\right)_{3.2} \cdot 10 \mathrm{H}_{2} \mathrm{O}$ (Bigham and others, 1994). In later reports, Bigham, Schwertmann, and $\mathrm{Pfab}$ (1996a) used $\mathrm{Fe}_{8} \mathrm{O}_{8}(\mathrm{OH})_{6} \mathrm{SO}_{4}$ and Bigham and others $(1996 \mathrm{~b})$ used $\mathrm{Fe}_{8} \mathrm{O}_{8}(\mathrm{OH})_{5.5}\left(\mathrm{SO}_{4}\right)_{1.25}$. The results of this study support a formula with an 8:1.25 molar ratio of $\mathrm{Fe}: \mathrm{SO}_{4}$.

A major reason for our interest in schwertmannite-rich material is that metals such as $\mathrm{Cd}, \mathrm{Cu}, \mathrm{Pb}, \mathrm{Zn}$, and As may be sorbed to this phase and may be released during desporption in concentrations that are toxic to aquatic organisms (Lee, 1975; Jenne, 1977; Morel and Gschwend, 1987; Stumm and Morgan, 1996). A second reason for the present report is our recognition that schwertmannite-rich material causes a significant drop in $\mathrm{pH}$ by reaction with deionized water because of dissolution of schwertmannite. This acid generation will enhance solubility of toxic metals temporarily sequestered in both the suspended and precipitated Fe-rich solids in the stream bed. Significant acid generation from natural schwertmannite-rich material in a stream bed has not been previously reported. However, Bigham and others (1996b) measured significant acid generation in long-term exposure of synthetic schwertmannite to distilled water (initial pH $=3.9$ ) that appeared to equilibrate in about 1,000 days, and traces of goethite were detected as a decomposition product after 65 days. In that experiment, there was a nonstoichiometric release of $\mathrm{Fe}$ and $\mathrm{SO}_{4}$, and the molar ratio of $\mathrm{H}^{+}: \mathrm{SO}_{4}^{-2}$ was $2: 1$. The following was given by Bigham and others (1996b, $\mathrm{p}$. 2114) for the hydrolysis of schwertmannite:

$\mathrm{Fe}_{8} \mathrm{O}_{8}(\mathrm{OH})_{5.5}\left(\mathrm{SO}_{4}\right)_{1.25(s)}+2.5 \mathrm{H}_{2} \mathrm{O}_{(\mathrm{l})} \Rightarrow 8 \mathrm{FeOOH}_{(\mathrm{s})}+2.5 \mathrm{H}_{(\mathrm{aq})}^{+}+1.25 \mathrm{SO}_{4}{ }^{2-}(\mathrm{aq})$.

They concluded that "a complete description of aqueous solubility relationships for schwertmannite would presumably require a combination of solubility calculations and surface complexation modeling" (Bigham and others, 1996b).

The selection of the stream reaches and sampled sites studied (fig. 1) was based on prior investigations which showed that very high concentrations of iron and associated potentially toxic metals occur in both Cement Creek and Mineral Creek in the Animas River headwaters, and that colloidal Fe may be a dominant 
contributor to water quality degradation downstream (Owen, 1997; Church and others, 1997). Selection of the two sampled sites in the Boulder River headwaters was partly based on the fact that Nimick and Cleasby (1998) measured elevated toxic metals in both Uncle Sam Gulch and Jack Creek (which is downstream from the large Bullion mine waste piles and associated acidic drainage water from an adit).

\section{CURRENT STUDY}

Schwertmannite-rich material has been identified in acidic drainage water in Colorado and Montana by $\mathrm{XRD}$, spectral reflectance analysis, and leaching experiments. Table 1 gives the locations of samples, $\mathrm{pH}$ of water, other minerals detected in the coatings, date collected, and $\mathrm{pH}$ of 1:4,000 (solid:water) leachates plus the concentrations of some trace metals. The Colorado samples are from sites $2,926 \mathrm{~m}(9,600 \mathrm{ft}$.) to $3,170 \mathrm{~m}(10,400 \mathrm{ft}$.) above mean sea level; those from Montana are from sites $2,134 \mathrm{~m}(7,000 \mathrm{ft}$.) to 2,243 $\mathrm{m}(7,360 \mathrm{ft}$.) above mean sea level. National Atmospheric Deposition data for the two nearest monitoring sites for the Colorado study area and the Montana study area are given in Appendix I. All of these samples are from stream beds except A98D17 which is from a mine adit drainage. The stream samples occur in two similar environments; one is downstream from the mixing of higher $\mathrm{pH}$ stream water which is met by lower $\mathrm{pH}$ Fe-bog water, as in Cement Creek (fig. 1), and the other is where higher $\mathrm{pH}$ stream water mixing with lower $\mathrm{pH}$ mine waste water runoff, or mine adit drainage water, for the two Montana occurrences. Except for the 30-day samples, all were collected from rocks or boulders by scraping off the orange precipitate with a wooden "tongue depressor" and placing the sample in a sealed plastic container which was refrigerated until air drying in the laboratory. The 30 day precipitates were collected on three or four $1.5 \times 4.0 \times 30 \mathrm{~cm}$ wooden stakes at each of three sites along Cement Creek. The stakes were submerged (horizontally) downstream from Fe bogs with low $\mathrm{pH}$ water that emerge near stream level near Prospect Gulch. The precipitates were allowed to air dry in the laboratory before removal from the stakes. The thickness of the coatings ranged from about $2-7 \mathrm{~mm}$. Comparable thicknesses of schwertmannite were observed on the boulders. All samples were sieved (stainless steel) to remove pine needles, other leaves, and plant stems before weighing. Based upon the masses of schwertmannite on the measured areas of the wooden stakes placed at three sites (A98D16, A98D12, and A98D14, fig 1.) for 30 days, we can estimate that $\mathrm{Fe}$ precipitation was about $370 \mathrm{~kg} \mathrm{~d}^{-1}$ in the $3.5 \mathrm{~km}$ stream reach studied. The $\mathrm{pH}$ of waters from which schwertmannite-rich material was collected ranged from 3.08 to 4.25 (table 1), which is within the $\mathrm{pH}$ range of 2.8 to 4.5 that Bigham and others (1996b) have shown is most favorable for schwertmannitedominant precipitates.

At three sites sampled, schwertmannite-rich material collected in August, 1997 had no XRD-detectable goethite; for material collected in early September, 1998 from the same sites, all contained goethite, in addition to schwertmannite.

The amounts of $\mathrm{Cu}, \mathrm{Zn}, \mathrm{As}$, and $\mathrm{Pb}$ sorbed in the schwertmannite-rich material from Cement Creek varies significantly, even for samples collected from the same three sample sites (table 1). 
Table 1. Locations of schwertmannite-rich orange deposits in Colorado and Montana with pH of stream water, other minerals, date collected, and concentrations of $\mathrm{Cu}, \mathrm{Zn}, \mathrm{As}$, and $\mathrm{Pb}$ in schwertmannite-rich material. $[\mathrm{XRD}=\mathrm{X}$-ray diffraction, $\mathrm{n} . \mathrm{d}=$ not determined, $*=$ mean of three measurements, $\#$ \# = Arsenic greater that 1 weight percent]

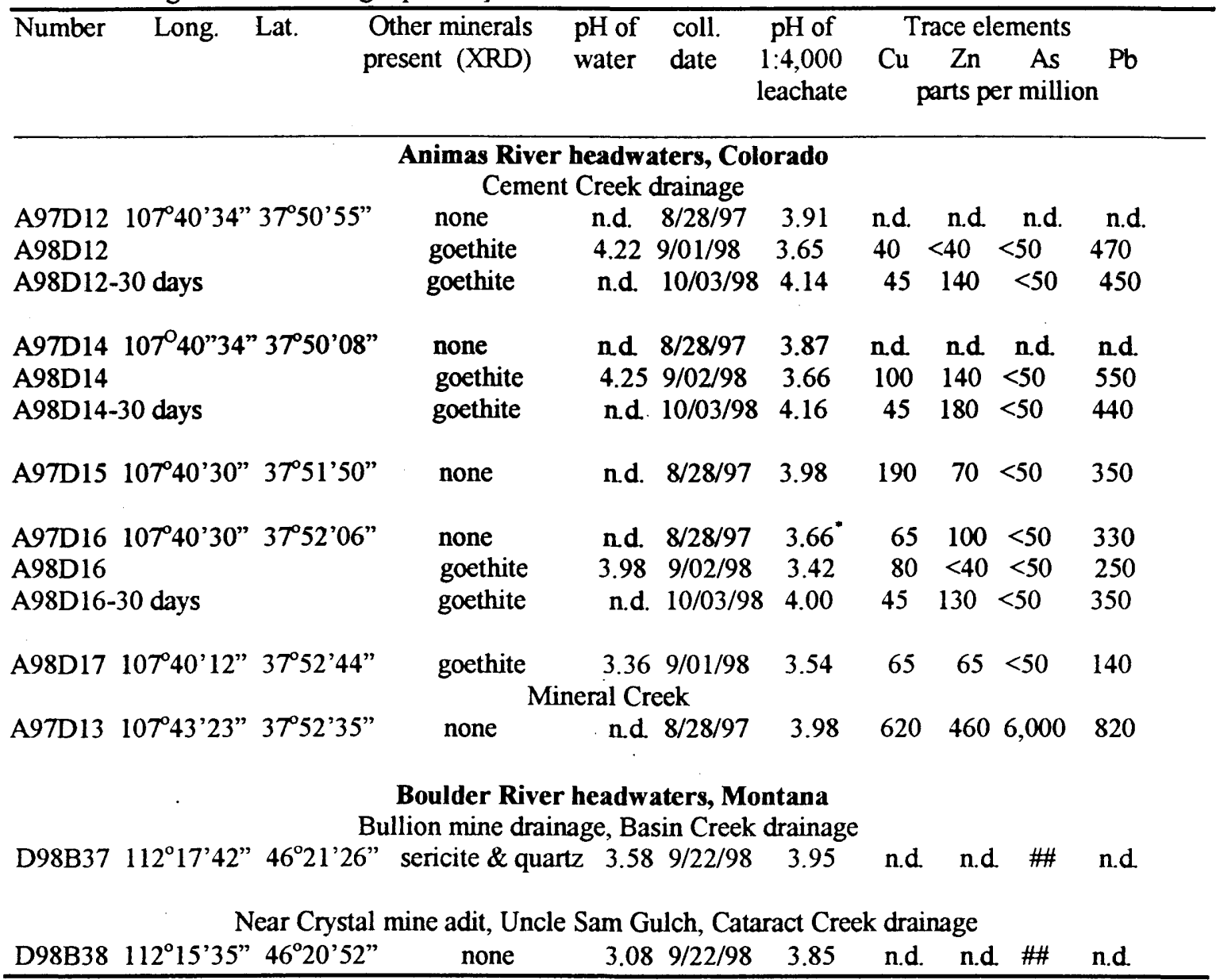

Table 2 shows the concentrations of several elements and sulfate in water and $\mathrm{pH}$ at four sites sampled in Cement Creek. The pH of water at site A98D18 is elevated due to upstream liming treatment of drainage water by Sunnyside Gold Corporation to remove metals by precipitation. Figure 2 shows the relations of the concentrations of these elements with respect to the Fe bog between sites 18 and 16. Data in Table 2 show that $\mathrm{Al}$ and $\mathrm{Fe}$ concentrations are four or five times higher at site A98D16 which is about $1.3 \mathrm{~km}$ downstream from the Fe bog (Fig. 2). $\mathrm{Zn}$ is only enhanced about 20 percent but $\mathrm{Pb}$ is increased by about 3.5 times and $\mathrm{Cu}$ is increased about 2.4 times. 
Table 2. Concentrations of cations and sulfate in water samples, and $\mathrm{pH}$ of water at four sites along Cement Creek collected at the time the A98D-series schwertmannite-rich samples were obtained. [Water samples were $0.45 \mu \mathrm{m}$ filtered and acidified at the time of collection. Cation analysis by ICP/MS ACTLABS, 15485 W. $44^{\text {th }}$ Ave. Golden CO 80403 . Sulfate analysis by Huffman Laboratories, Inc. 4630 Indiana St. Golden, CO 80403]

\begin{tabular}{lccccccccccccc}
\hline Sample & $\mathrm{Na}$ & $\mathrm{Mg}$ & $\mathrm{Al}$ & $\mathrm{K}$ & $\mathrm{Ca}$ & $\mathrm{Mn}$ & $\mathrm{Fe}$ & $\mathrm{Cu}$ & $\mathrm{Zn}$ & $\mathrm{Cd}$ & $\mathrm{Pb}$ & $\mathrm{SO}_{4}$ & $\mathrm{pH}$ \\
& -0 & & & & & \\
A98D18 & 2020 & 4500 & 840 & 640 & 149000 & 1280 & 2330 & 8.8 & 400 & 2 & 3.4 & 380 & 5.51 \\
A98D16 & 2060 & 5040 & 4110 & 1100 & 142500 & 1320 & 9360 & 21 & 500 & 2 & 12 & 450 & 3.98 \\
A98D12 & 2150 & 4730 & 3410 & 970 & 137300 & 1390 & 3480 & 26 & 470 & 2 & 13 & 420 & 4.22 \\
A98D14 & 2190 & 4760 & 3400 & 1670 & 135500 & 1400 & 2490 & 29 & 480 & 2 & 13 & 430 & 4.25 \\
\hline
\end{tabular}

\section{DEIONIZED WATER LEACHATES OF A SCHWERTMANNITE-RICH SAMPLE FROM CEMENT CREEK NEAR SILVERTON, COLORADO}

Three one-gram splits from air-dried A97D16 solids (table 1) were each exposed to 2, 3, and $4 \mathrm{~L}$ of deionized water $(\mathrm{pH}=5.00)$, respectively, in nine serial leaches, at rest, side-by-side, for $24 \mathrm{~h}$ each as

\begin{tabular}{|c|c|c|}
\hline $\begin{array}{l}\text { SAMPLE } \\
\quad X\end{array}$ & $\begin{array}{l}\text { SAMPLE } \\
\text { Y }\end{array}$ & $\begin{array}{l}\text { SAMPLE } \\
\quad Z\end{array}$ \\
\hline $\begin{array}{l}1 \text { GRAM } \\
\text { A97D16 } \\
\text { EXPOSED } \\
\text { TO } 2 \text { L OF } \\
\text { DEIONIZED } \\
\text { WATER-24 h }\end{array}$ & $\begin{array}{l}1 \text { GRAM } \\
\text { A97D16 } \\
\text { EXPOSED } \\
\text { TO } 3 \text { L OF } \\
\text { DEIONIZED } \\
\text { WATER-24 h }\end{array}$ & $\begin{array}{l}1 \text { GRAM } \\
\text { A97D16 } \\
\text { EXPOSED } \\
\text { TO } 4 \text { L OF } \\
\text { DEIONIZED } \\
\text { WATER-24 h }\end{array}$ \\
\hline \multicolumn{3}{|c|}{$\begin{array}{l}\text { MEASURE pH OF EACH LIQUID, SAMPLE } \\
\text { EACH LIQUID FOR CATIONS AND ANIONS, } \\
\text { RESPECTIVELY, USING O.45 MICRON } \\
\text { FILTERS, ACIDIFY CATION SAMPLE } \\
\text { AND DECANT LIQUID FROM EACH } \\
\text { SAMPLE }\end{array}$} \\
\hline \multicolumn{3}{|c|}{$\begin{array}{l}\text { REPEAT THIS PROCEDURE EIGHT MORE } \\
\text { TIMES USING THE SAME SOLIDS. X. Y. \& Z }\end{array}$} \\
\hline
\end{tabular}

Appendix II lists the concentrations of ten cations, sulfate, final pH, and exposure time for all 27 leachates. Dissolved Fe was detected in only four of the 27 leachates and amounted to a total of $43-62 \mu \mathrm{g} \mathrm{g}^{-1}$ of the samples or 0.004 to 0.006 weight percent of the original samples. Detection limits for Fe were $0.2 \mu \mathrm{g} \mathrm{L}^{-1}$. Between $0.5-10.3 \mathrm{mg} \mathrm{L}^{-1}$ of sulfate was found in all 27 leachates. Concentrations of $\mathrm{H}^{+}$and sulfate in solution show a linear relationship $\left(\mathrm{R}^{2}=0.98\right)$ for the leachates (figure 3 , Appendix III). The sums of the mmol ratios of $\mathrm{H}^{+}: \mathrm{SO}_{4}^{-2}$ for each of the three sets of serial leaches are 3.70:1, 3.92:1, and 4.09:1, averaging 3.90:1 which is more than twice the ratio obtained by Bigham and others (1996b). They found a ratio of 1.81:1 after 1739 days. The reason for this difference in these ratios is probably due to the fact that the leaching done here was a very short term compared with that of Bigham and others (1996b) and equilibrium was not reached in these short term leaches. In addition, adsorption of sulfate onto the precipitated solid $\mathrm{Fe}$ phases cannot be quantified. The sum of all dissolved cations in all of the nine serial leachates is less than one $\mathrm{mg}$. The sum of $\mathrm{H}^{+}$for each of the nine serial leaches of the three samples ranges from 1.938-2.248 millimoles $\mathrm{g}^{-1}$ of solid.

The chemical compositions of the untreated and leached samples are given in Table 3. 
The chemical data for the three untreated samples show $\mathrm{Fe}$ and $\mathrm{S}$ are the major elements and that molar Fe:S is 6.3-6.5 which is essentially identical to the ratio (6.4) given by Bigham and others (1996b) for schwertmannite. The concentrations of sorbed $\mathrm{Cu}, \mathrm{Zn}$, and $\mathrm{Pb}$ are noteworthy in terms of their potential toxicity to aquatic life, if released to the water. For the sample splits leached nine times, $\mathrm{S}$ has been reduced in concentration and $\mathrm{Fe}$ has been enhanced. This can mostly be attributed to the loss of sulfate in the dissolution of schwertmannite and the retention of Fe as precipitates of XRD-amorphous ferric oxides. XRD analysis shows that schwertmannite is a major phase in the three splits leached nine times (table 2), even though almost half of the schwertmannite was removed (dissolved), based on the dissolved sulfate in each of the leachates. The leached schwertmannite-rich samples have Fe:S in the range of 9.9-10.8 (table 3) but these values may be too high, if sulfate was adsorbed on resulting amorphous Fe oxides or remaining schwertmannite as was observed by Rose and Ghazi (1997). Small losses in Na, Al, and Ca observed for the leached samples are not considered significant.

Table 3. Chemical compositions of three untreated A97D16 schwertmannite-rich samples and three splits $\mathrm{X}, \mathrm{Y}$, and Z-each leached nine times for $24 \mathrm{~h}$. ICP/AES analysis except for total sulfur analyzed by Huffman Laboratories, Inc. 4630 Indiana Street, Golden, Co 80403. [n.d. = not determined ; Ag, Be, Cd, $\mathrm{Co}, \mathrm{Cr}, \mathrm{Eu}, \mathrm{La}, \mathrm{Li}, \mathrm{Mo}, \mathrm{Ni}, \mathrm{Y}$, and $\mathrm{Yb}$ are $<5$ parts per million; $\mathrm{As}, \mathrm{Au}, \mathrm{Bi}, \mathrm{Ce}, \mathrm{Ga}, \mathrm{Ho}, \mathrm{Nb}, \mathrm{Nd}$, $\mathrm{Sn}$, and Th are $<20$ parts per million.]

\begin{tabular}{|c|c|c|c|c|c|c|}
\hline \multirow[b]{2}{*}{ Element } & \multicolumn{3}{|c|}{ Untreated Samples } & \multicolumn{3}{|c|}{ Splits Leached Nine Times } \\
\hline & A97D16R & A97D16B & A97D16N & A97D16X & A97D16Y & A97D16Z \\
\hline $\mathrm{Na}$ & 0.06 & 0.1 & 0.08 & 0.03 & 0.03 & 0.03 \\
\hline $\mathrm{Mg}$ & 0.1 & 0.2 & 0.07 & 0.26 & 0.2 & 0.2 \\
\hline $\mathrm{Al}$ & 1.2 & 1.6 & 0.8 & 0.96 & 0.78 & 0.79 \\
\hline$P$ & 0.1 & 0.1 & 0.08 & 0.09 & 0.09 & 0.08 \\
\hline$S$ & 3.98 & 3.68 & 4.11 & 2.71 & 2.58 & 2.54 \\
\hline K & 0.32 & 0.52 & 0.2 & 0.26 & 0.2 & 0.2 \\
\hline $\mathrm{Ca}$ & 0.09 & 0.1 & 0.06 & $<0.01$ & $<0.01$ & $<0.01$ \\
\hline $\mathrm{Ti}$ & 0.07 & 0.09 & 0.04 & 0.05 & 0.05 & 0.05 \\
\hline $\mathrm{Fe}$ & 44 & 42 & 46 & 47 & 48 & 48 \\
\hline Organic Carbon & 1.1 & 0.9 & n.d. & n.d. & n.d. & n.d. \\
\hline $\mathrm{Ba}$ & 830 & 850 & 800 & 840 & 870 & 880 \\
\hline $\mathrm{Cu}$ & 72 & 64 & 65 & 100 & 58 & 56 \\
\hline Mn & 140 & 220 & 71 & 68 & 46 & 44 \\
\hline $\mathrm{Pb}$ & 350 & 330 & 300 & 270 & 280 & 280 \\
\hline $\mathrm{Sr}$ & 28 & 50 & 10 & 20 & 5 & 6 \\
\hline V & 75 & 80 & 54 & 59 & 56 & 56 \\
\hline $\mathrm{Zn}$ & 94 & 150 & 54 & 96 & 53 & 44 \\
\hline Molar Fe:S & 6.3 & 6.5 & 6.4 & 9.9 & 10.6 & 10.8 \\
\hline
\end{tabular}


Table 4 shows the total amounts of $\mathrm{Fe}, \mathrm{Cu}, \mathrm{Zn}, \mathrm{Pb}$, and sulfate in all of the nine leachates for each split from sample A97D16. Although dissolved $\mathrm{Fe}$ was detected in only the first of the nine leachates of each split (with one exception), $\mathrm{Cu}, \mathrm{Zn}$, and $\mathrm{Pb}$ were present in all 27 leachates (Appendix II). These data demonstrate the leachability or mobility of $\mathrm{Cu}, \mathrm{Zn}$, and $\mathrm{Pb}$ by initial $\mathrm{pH} 5$ water, even after multiple exposures to large volumes of water. The amounts of $\mathrm{Pb}$ in each of the first leachates of each sample ranged from 5.1-10.8 $\mu \mathrm{g} \mathrm{L}^{-1}$ which exceeds the Class 1 Aquatic Life standard (which is $4 \mu \mathrm{g} \mathrm{L}^{-1}$ for alkalinity values of $0-100 \mathrm{mg} \mathrm{L}^{-1}$ ). Trace metal release is clearly important to the ultimate fate of sorbed toxic metals associated with schwertmannite-rich and amorphous ferric oxide precipitates which may release sorbed metals when exposed to unsaturated rainfall or snowmelt runoff, or if $\mathrm{pH}$ of water is raised by remediation.

Table 4. Sum of total mass of dissolved $\mathrm{Fe}, \mathrm{Cu}, \mathrm{Zn}, \mathrm{Pb}$, and sulfate in nine serial leachates of one gram of schwertmannite-rich material. [ ICP/MS analysis of cations by ACTLABS, $15485 \mathrm{~W} .44^{\text {th }}$ Ave., Goldlen, CO 80403 and sulfate analysis by Huffmann Laboratories, Inc. 4630 Indiana Street, Golden, CO 80403.]

\begin{tabular}{|c|c|c|c|c|c|c|}
\hline$\overline{\text { Sample }}$ & $\mathrm{Fe}$ & $\mathrm{Cu}$ & $\begin{array}{c}\mathrm{Zn} \\
\text { ams-.. }\end{array}$ & $\mathrm{Pb}$ & $\begin{array}{c}\mathrm{SO}_{4} \\
\text { milligrams }\end{array}$ & $\begin{array}{l}\text { Leachate } \\
\text { volume, } \mathrm{L}\end{array}$ \\
\hline A97D16X & 62.4 & 11.5 & 25.7 & 44.5 & 50.8 & 18 \\
\hline A97D16Y & 48 & 13.3 & 45.7 & 43.6 & 51.0 & 27 \\
\hline A97D16Z & 43 & 13.2 & 46.9 & 40.1 & 56.4 & 36 \\
\hline
\end{tabular}

The serial leaching experiments were done to simulate the influence of relatively pure water of $\mathrm{pH} 5.0$ (representative of rainfall or snowmelt runoff), on schwertmannite-rich and ferric oxide precipitates. It is important to note that these precipitates accumulate significantly at low-flow conditions of late August through October in the Animas and Boulder River headwaters. It is significant that these precipitates generate large amounts of acid in $24 \mathrm{~h}$ when exposed to large volumes of unsaturated water of $\mathrm{pH}$ of about 5.

Nimmo and others (1998, p. 917), in a study of the New World mining district (upstream from Yellowstone National Park), observed that anoxia was principally responsible for daphnid and fathead minnow mortality in $24 \mathrm{~h}$ for stream waters that precipitated Fe-rich phases. Dissolved oxygen concentrations were reduced by half in two $h$ due to high chemical oxygen demand of the Fe-oxide precipitates. The study of Nimmo and others (1998) also implicated $\mathrm{Cu}$ as the principal element that is detrimental to trout viability and they state that "It is hypothesized that the availability of copper and metals is closely linked to fine sedimentary clays or colloids and to floodplain storage of tailings, which are mobilized, transported and deposited downstream by high flows occurring principally in the spring." They also observed that copper at sites upstream of the park boundary ranged from 7 to $11 \mu \mathrm{g} \mathrm{L}^{-1}$ in the spring of 1995 and from 3 to $9 \mu \mathrm{g} \mathrm{L}^{-1}$ in the fall of 1995 .

Table 3 of this report shows that leaching of schwertmannite-rich samples from Cement Creek of one gram each, which were exposed to $18,000,27,000$, and $36,000 \mathrm{ml}$ of deionized water released 11.5-13.3 $\mu \mathrm{g}$ of $\mathrm{Cu}$ in nine serial leaches. Appendix II shows that the individual leaches produced $\mathrm{Cu}$ concentrations well below the Class 1 Aquatic Life Standards. We do not know if this might simulate spring runoff conditions, but it must be considered in light of the studies of Nimmo and others (1998).

\section{AMORPHOUS ORANGE PRECIPITATES FORMED IN LESS ACIDIC WATER}

Two samples of Fe-rich (> $30 \mathrm{wt}$. \%) X-ray diffraction-amorphous orange precipitates obtained from the Cement Creek drainage (Animas River headwaters) in the fall of 1998 had high concentrations of sorbed $\mathrm{Cu}, \mathrm{Zn}$, and $\mathrm{Pb}$. Table 5 and Figure 1 shows the locations, water $\mathrm{pH}$, and concentrations of $\mathrm{Cu}, \mathrm{Zn}$, and $\mathrm{Pb}$ in these air-dried precipitates. Although the water cannot be considered harmful with respect to acidity, the high concentrations of $\mathrm{Cu}, \mathrm{Zn}$, and $\mathrm{Pb}$ in the precipitates are a potential threat to downstream aquatic life if they are desorbed during spring runoff. 
Table 5. Locations, water $\mathrm{pH}$, collection date, and concentrations of $\mathrm{Cu}, \mathrm{Zn}$, and $\mathrm{Pb}$ in two amorphous $\mathrm{Fe}-$ rich orange precipitates in the Cement Creek drainage near Silverton, Colorado of the Animas River headwaters.

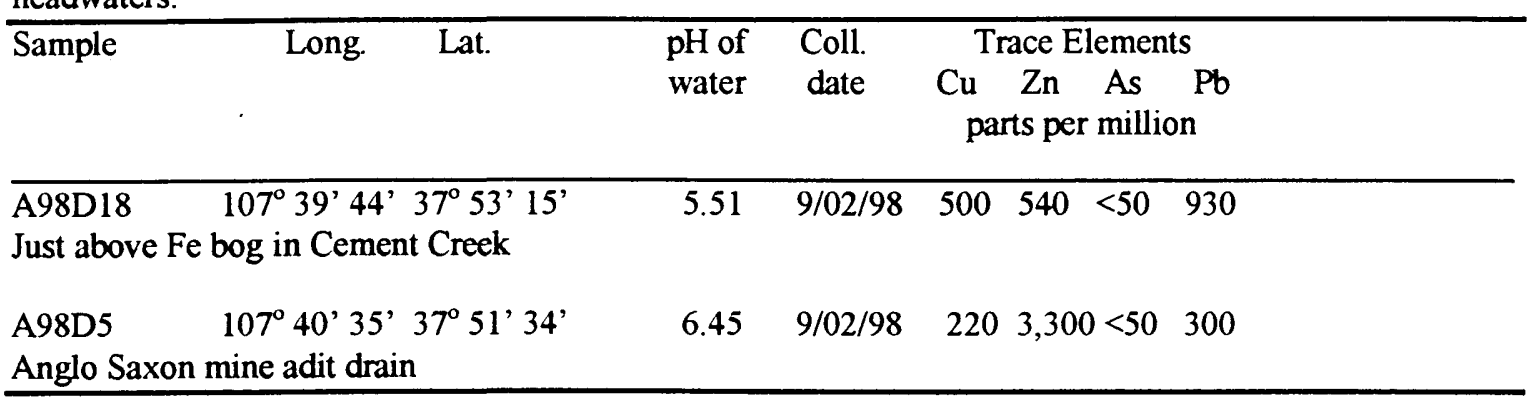

In order to evaluate the potential mobility of some of the elements in the two $\mathrm{Fe}$-rich precipitates listed in Table 5, they were exposed to a pH of 3.66 leachate of schwertmannite A97D16 (obtained by exposure of $1 \mathrm{~g}$ of A97D16 to $4 \mathrm{~L}$ deionized water for $24 \mathrm{~h}$ ), here called the primary leachate. Two ratios of solid:primary leachate were used, one was $1: 1,000$ and the other was 1:4,000; they were leached without agitation. Analysis of the primary leachate and the concentrations of selected elements in subsequent leachates of the two Fe-rich orange precipitate samples are shown in Table 6. These results can be inferred to indicate that when the XRD-amorphous Fe-rich precipitates are flushed into the schwertmannite-rich environments of Cement Creek during spring runoff, significant amounts of metals such as $\mathrm{Al}, \mathrm{Cu}, \mathrm{Cd}$ and $\mathrm{Zn}$ may be desorbed from them. We do not claim that these experiments simulate natural conditions, in the absence of field tests. However, these results indicate potential toxic metal mobility for Fe-rich precipitates when they are exposed to acid-generating schwertmannite-rich solids in Cement Creek during springsummer runoff.

Table 6. Concentrations of selected elements in the primary schwertmannite leachate and the subsequent leachates of two Fe-rich orange precipitates. [0.45 $\mu \mathrm{m}$ filtered and acidified; ICP/MS analysis by ACTLABS, 15485 W. $4^{\text {th }}$ Ave., Golden, CO 80403

\begin{tabular}{lccccccc}
\hline $\begin{array}{l}\text { Sample } \\
\text { (solid:liquid } \\
\text { leach ratio) }\end{array}$ & $\mathrm{Al}$ & $\mathrm{Mn}$ & $\mathrm{Fe}$ & $\mathrm{Cu}$ & $\mathrm{Zn}$ & $\mathrm{Cd}$ & $\mathrm{Pb}$ \\
\hline $\begin{array}{l}\text { Primary leachate } \\
\text { from schwertmannite }\end{array}$ & 41 & 12 & 49 & 2.6 & 8.9 & 0.08 & 13.7 \\
A98D5 & & & & & & & \\
$(1: 1000)$ & 137 & 184 & 5 & 6.6 & 646 & 0.68 & $>0.1$ \\
$(1: 4000)$ & 176 & 83 & 22 & 14.9 & 279 & 0.62 & 0.9 \\
& & & & & & & \\
A98D18 & 1000 & 75 & 68 & 73 & 192 & 0.65 & 1.5 \\
$(1: 1000)$ & 600 & 29 & 72 & 65 & 63 & 0.30 & 7.2 \\
$(1: 4000)$ & & & & & & &
\end{tabular}

\section{SUMMARY}

Schwertmannite-rich precipitates are reservoirs for acid-generating potential and toxic-metal release to aquatic environments when exposed to unsaturated water of $\mathrm{pH} 5$ or higher.

Precipitation of schwertmannite, formation of amorphous colloidal Fe oxide, goethite, or ferrihydrite, result in chemical depletion of dissolved oxygen that might inhibit life sustainability in aquatic environments.

Schwertmannite-rich and amorphous colloidal Fe oxides formed at low-flow stream conditions may be mobilized at high-flow stream conditions and pollute initially unsaturated snow-melt runoff by generating acidic conditions and cause mobility of sorbed toxic metals such as $\mathrm{Cu}, \mathrm{Zn}$, and $\mathrm{Pb}$ in downstream environments. 


\section{REFERENCES CITED}

Bigham, J.M., Schwertmann, U., Carlson, L., and Murad, E., 1990, A poorly crystallized oxyhydroxysulfate of iron formed by bacterial oxidation of $\mathrm{Fe}(\mathrm{II})$ in acid mine waters Geochimica et Cosmochimica Acta, v. 54, pp. 2743-2758.

Bigham, J.M., Carlson, L., and Murad,E., 1994, Schwertmannite, a new iron oxyhydroxysulfate from Pyhasalmi, Finland, and other localities: Mineralogical Magazine, v. 58, pp. 641-648.

Bigham, J.M., Schwertmann, U., and Pfab, G., 1996a, Influence of $\mathrm{pH}$ on mineral speciation in a bioreactor simulating acid mine drainage: Applied Geochemistry, v. 11 , pp. 845-849.

Bigham, J.M., Schwertmann, U., Traina, S.J., Winland, R.L., and Wolf, M., 1996b, Schwertmannite and the chemical modeling of iron in acid sulfate waters: Geodhimica et Cosmochimica Acta, v. 60, pp. 2111-2121.

Church, S.E., Kimball, B.A., Fey, D.L., Ferderer, D.A., Yager, T.J., and Vaughan, R. B., 1997, Source, transport, and partitioning of metals between water, colloids, and bed sediments of the Animas River, Colorado: U.S. Geological Survey Open-File Report 97-151, $135 \mathrm{p}$.

Jenne, E.A., 1977, Trace element sorption by sediments and soils--sites and processes: Symposium on Molybdenum in the environment (eds. W. Chappell and K. Peterson), pp. 425-552. Marcel Dekker, New York.

Kimball, B.A., Callendar, E., and Axtmann, E.V., 1995, Effects of colloids on metal transport in a river receiving acid mine drainage, Upper Arkansas River, Colorado: Applied Geochemistry, v. 10, pp. 285-306.

Lee, G., 1975, Role of hydrous metal oxides in the transport of heavy metals in the environment: in Heavy Metals in the Aquatic Environment (ed. P. Krenkel), pp. 137-147, Pergamon Press, Oxford.

Morel, F.M.M., and Gschwend, P. M., 1987, The role of colloids in the partitioning of solutes in natural waters: in Aquatic Surface Chemistry (ed. W. Stumm), pp. 405422, Wiley, New York.

Nimmick, D.A., and Cleasby, T.E., 1998, What streams are affected by abandoned mines? - Characterization of Water quality in the streams of the Boulder River watershed, Montana: in Science for watershed decisions on abanndoned mine lands: Review of preliminary results, Denver, Colorado, February 4-5, 1998, p. 9.

Nimmo, D.R., Willox, M.J., Lafrancois, T.D., Chapman, P.L., Brinkman, S.F., and Greene, J.C., 1998, Effects of metal mining and milling on boundary waters of Yellowstone National Park, USA: Environmental Management, v. 22, pp. 913-926.

Owen, J.R., 1997, Water quality and sources of metal loading to the Upper Animas River Basin: Colorado Department of Public Health and Environment, $25 \mathrm{p}$.

Ranville, J.F., Smith, K.S., Macalady, D.L., and Rees, T.F., 1989, Colloidal properties of flocculated bed material in a stream contaminated by acid mine drainage, St. Kevin Gulch, Colorado, in Mallard, G.E., and Ragone, S.E., eds. U.S. Geological Survey Toxic Substances Program-Proceedings of the technical meeting, Phoenix, Arizona, September 26-30, 1988: U.S. Geological Survey Water-Resources Investigations Report 88-4220, pp. 111-118.

Rose, S., and Ghazi, A.M., 1997, Release of sorbed sulfate from iron oxyhydroxides precipitated from acid mine drainage associated with coal mining: Environmental Science Technology, v. 31, pp. 2136-2140.

Runnells, D:D., and Rampe, J.J., 1989, Natural clean-up of a stream contaminated by mine and mill wastes: A reaction analogous to liming in water treatment, in Miles, D.L., ed., Proceedings of the $6^{\text {th }}$ International Symposium on Water-Rock Interaction, Malvern, 3-8 August 1989, Rotterdam: A.A. Balkema, pp. 597-598.

Stumm, W. and Morgan, J.J., 1996, Aquatic Chemistry, $3^{\text {rd }}$ ed., New York: WileyInterscience, $1022 \mathrm{p}$. 

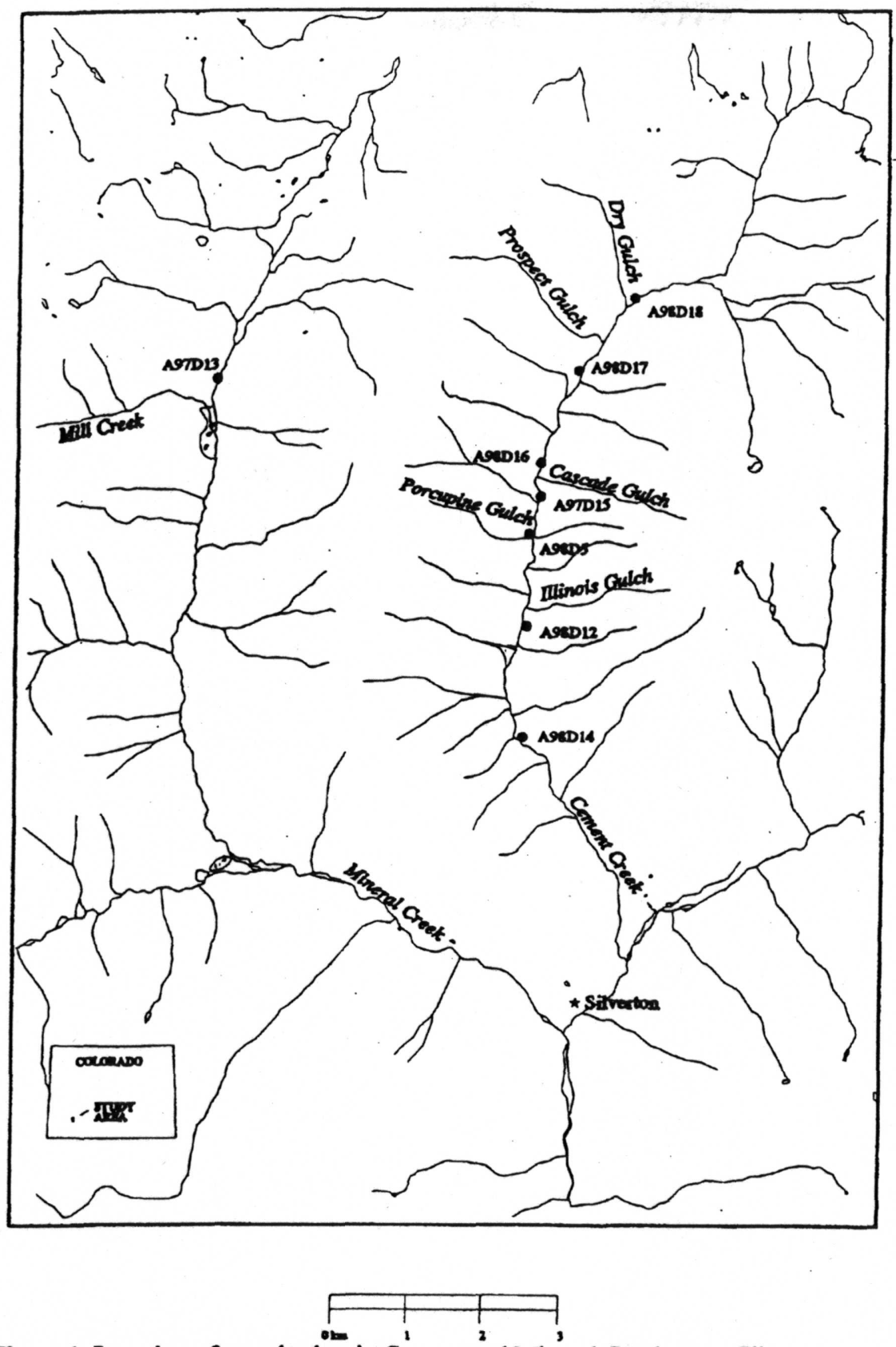

Figure 1. Location of sample sites in Cement and Mineral Creeks near Silverton, Colorado. The Fe bog extends from A98D17, upstream to the junction of Prospect Gulch with Cement Creek. 
Dissolved metals at 4 sites in Cement Creek from site A98D18 to site A98D14 9/2/98

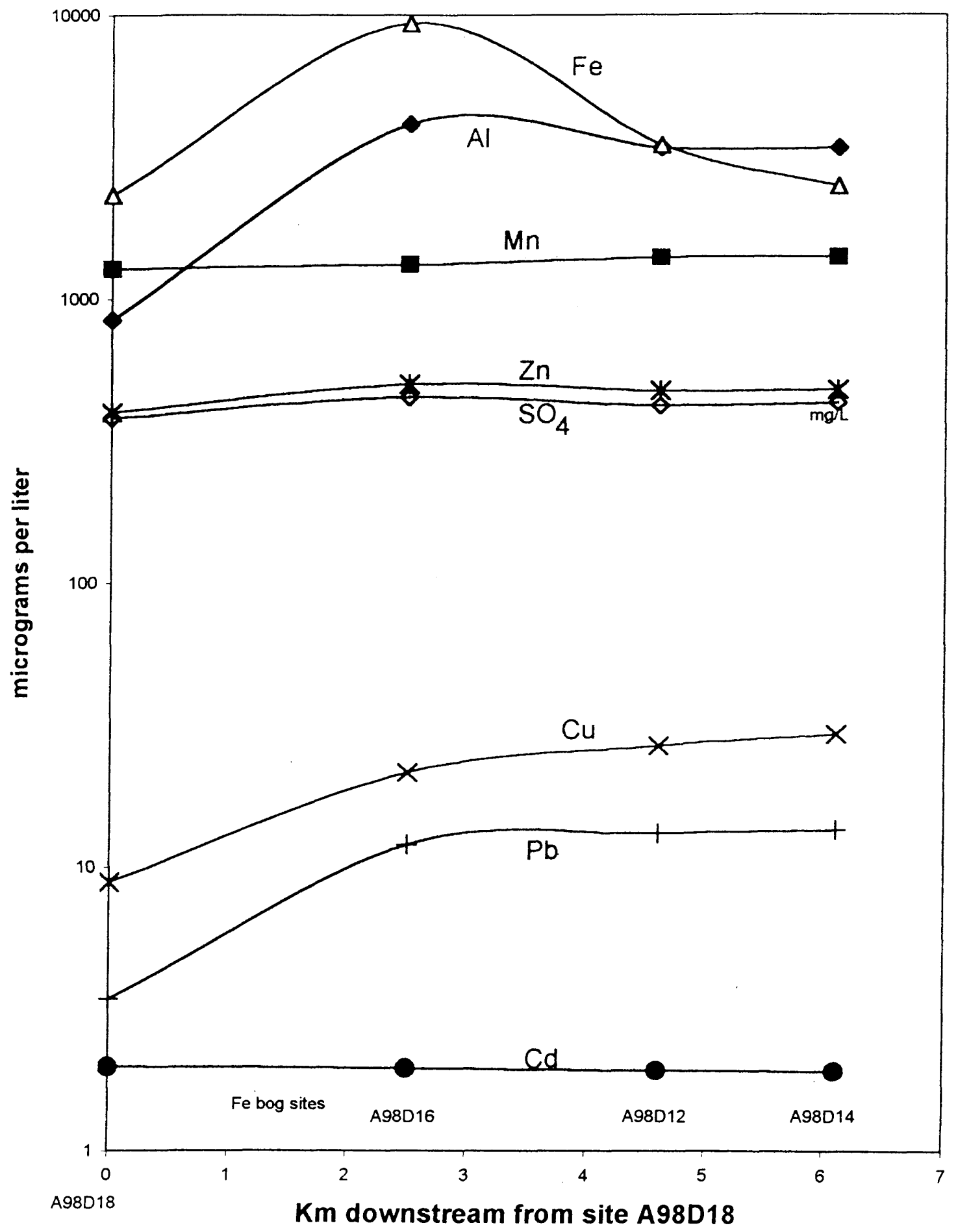

Figure 2. Concentrations of some metals and sulfate in water at four sites along Cement Creek. 


\section{MILLIMOLES OF SULFATE VS MILLIMOLES OF HYDROGEN IN X, Y, \& Z LEACHATES}

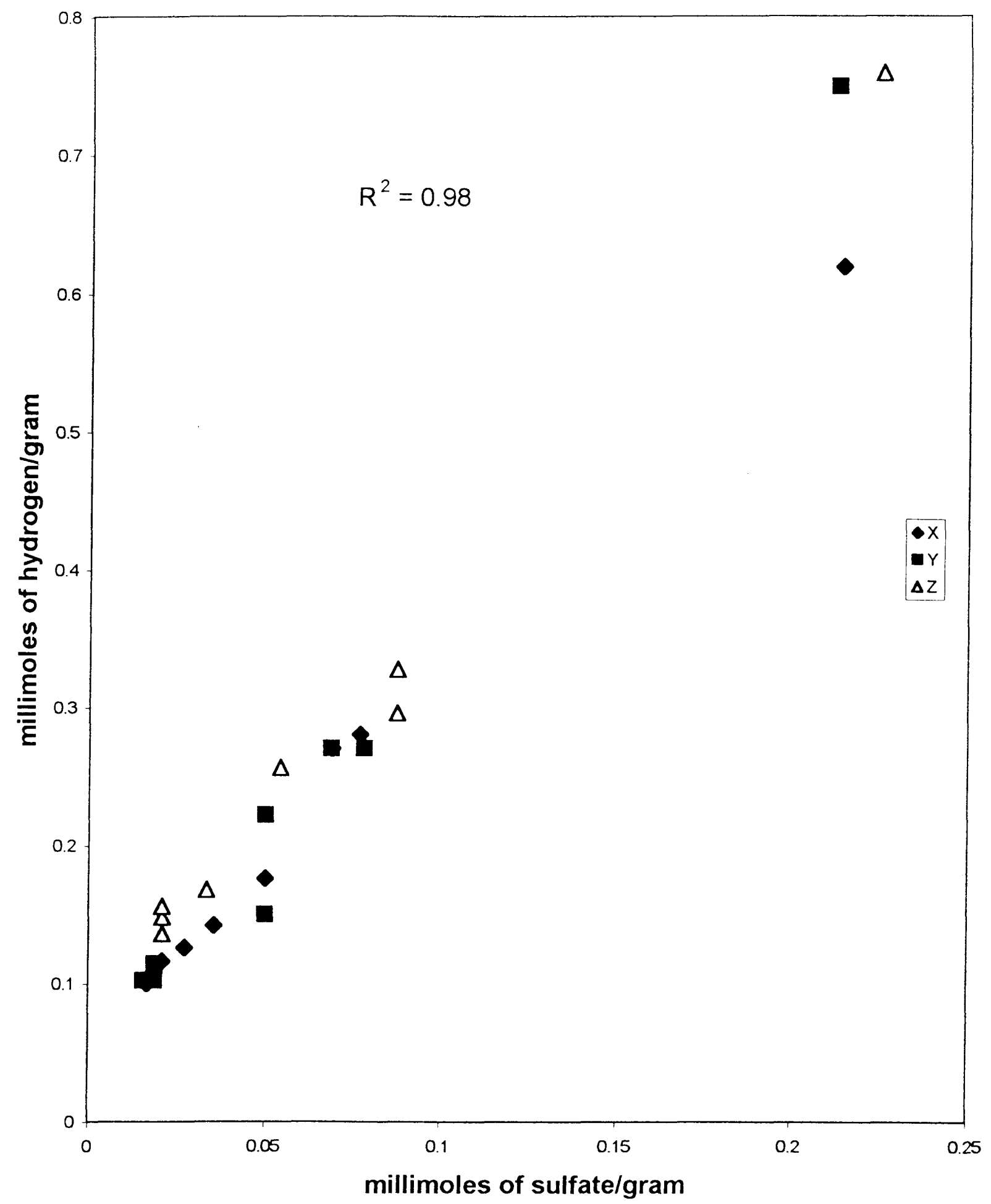

Figure 3. Relations of dissolved sulfate and $\mathrm{H}^{+}$in leachates of three schwertmannite-rich samples from site A98D16 along Cement Creek. 
Appendix I. National Atmospheric Deposition Program (NADP) data for monitoring sites near the Colorado study area and the Montana study area for 1997. [from http://nadp.sws. uiuc. edu/97 maps. Html]

NADP monitoring site for Cement and Mineral Creek Colorado study area is within $25 \mathrm{~km}$ of the CO96 (Molas Pass station)

\section{7}

$79 \mathrm{~cm}$

4.9

0.5

mean $\mathrm{SO}_{4}(\mathrm{mg} / \mathrm{L})$ :

mean

$\Sigma[\mathrm{Na}+\mathrm{K}+\mathrm{Mg}+\mathrm{Ca}](\mathrm{mg} / \mathrm{L}): \quad 0.21$
NADP monitoring site for the two Montana sites is less than $20 \mathrm{~km}$ from the MT07 (Clancy station)

1997

$41 \mathrm{~cm}$

5.1

0.4

0.196 
Appendix II. Major and minor cations and sulfate is nine leachates of A97D16X, A97D16Y, and A97D16Z. [cations determined by ACTLABS, 11485 West I-70 Frontage Road North, Wheat Ridge, CO 80033; sulfate determined by Huffman Laboratories, Inc., 4730 Indiana Street, Golden, $\mathrm{CO} 80403$ ]. $\mathrm{Na}$ is $<20 \mu \mathrm{g} \mathrm{L}^{-1}, \mathrm{~K}$ is $<10 \mu \mathrm{g} \mathrm{L}^{-1}, \mathrm{Sr}$ and $\mathrm{Ba}$ are $<3.0 \mu \mathrm{gL}^{-1}$, cations analyzed but which are not reported here were $<0.6 \mu \mathrm{gL}^{-1}$ for all 27 leachates.

\begin{tabular}{|c|c|c|c|c|c|c|c|c|c|c|c|c|c|}
\hline Exposure & $\begin{array}{l}\mathrm{Mg} \\
-. \\
\end{array}$ & $\mathrm{Al}$ & $\mathrm{Si}$ & $\begin{array}{l}\mathrm{Ca} \\
--\mathrm{mic} \\
\end{array}$ & $\begin{array}{l}\mathrm{Mn} \\
\text { orgrams }\end{array}$ & $\begin{array}{l}\mathrm{Fe} \\
\mathrm{S}^{-1}\end{array}$ & $\mathrm{Cu}$ & $\mathrm{Zn}$ & $\mathrm{Cd}$ & $\mathrm{Pb}$ & $\begin{array}{l}\mathrm{SO}_{4} \\
\mathrm{mgL}^{-1}\end{array}$ & $\begin{array}{r}\text { final } \\
\mathrm{pH}\end{array}$ & $\begin{array}{l}\text { Exposure } \\
\text { time, hr. }\end{array}$ \\
\hline \multicolumn{14}{|c|}{ Sample A97D16X-solid:liquid $=1: 2000$} \\
\hline 1 & 11.0 & 21.3 & 197 & 141 & 6.5 & 27.6 & 3.0 & 4.1 & 0.03 & 10.8 & 10.3 & 3.57 & 24 \\
\hline 2 & 0.9 & 4.0 & 191 & $<50$ & 0.4 & $<0.2$ & 0.4 & 2.0 & $<0.01$ & 3.4 & 3.3 & 3.89 & 24 \\
\hline 3 & $<0.5$ & 3.5 & 199 & $<50$ & 0.2 & $<0.2$ & 1.2 & 1.2 & 0.30 & 2.8 & 3.7 & 3.88 & 48 \\
\hline 4 & $<0.5$ & 1.5 & 164 & $<50$ & 0.2 & $<0.2$ & 0.3 & 1.3 & 0.02 & 1.8 & 2.4 & 4.00 & 24 \\
\hline 5 & 0.5 & $<0.1$ & 130 & $<50$ & 0.1 & $<0.2$ & 0.2 & 1.4 & $<0.01$ & 1.0 & 1.7 & 4.12 & 24 \\
\hline 6 & 2.0 & $<0.1$ & 165 & $<50$ & 0.1 & 3.6 & 0.3 & 1.1 & $<0.01$ & 0.7 & 1.3 & 4.20 & 24 \\
\hline 7 & $<0.5$ & $<0.1$ & 158 & $<50$ & 0.05 & $<0.2$ & $<0.1$ & 0.8 & $<0.01$ & 0.7 & 1.0 & 4.24 & 24 \\
\hline 8 & $<0.5$ & $<0.1$ & 162 & $<50$ & 0.07 & $<0.2$ & 0.1 & $<0.5$ & $<0.01$ & 0.6 & 0.9 & 4.25 & 24 \\
\hline 9 & $<0.5$ & $<0.1$ & 122 & $<50$ & 0.12 & $<0.2$ & 0.2 & 0.9 & $<0.01$ & 0.5 & 0.8 & 4.28 & 24 \\
\hline \multicolumn{14}{|c|}{ Sample A97D16Y-solid:liquid $=1: 3000$} \\
\hline 1 & 7.0 & 13.6 & 174 & 90 & 4.2 & 16.0 & 2.0 & 2.4 & 0.01 & 7.6 & 6.8 & 3.66 & 24 \\
\hline 2 & 1.0 & 1.6 & 128 & $<50$ & 0.2 & $<0.2$ & 0.3 & $<0.5$ & $<0.01$ & 1.7 & 2.2 & 4.00 & 24 \\
\hline 3 & $<0.5$ & 1.7 & 173 & $<50$ & 0.1 & $<0.2$ & 0.5 & 1.1 & 0.10 & 1.6 & 2.5 & 4.00 & 48 \\
\hline 4 & 0.5 & 1.1 & 166 & $<50$ & 0.1 & $<0.2$ & 0.4 & 2.6 & 0.01 & 1.3 & 1.6 & 4.10 & 24 \\
\hline 5 & $<0.5$ & 1.1 & 170 & $<50$ & 0.1 & $<0.2$ & 0.2 & 1.6 & 0.05 & 0.6 & 1.6 & 4.27 & 24 \\
\hline 6 & $<0.5$ & $<0.1$ & 151 & $<50$ & 0.1 & $<0.2$ & 0.1 & 4.6 & $<0.01$ & 0.5 & 0.6 & 4.40 & 24 \\
\hline 7 & $<0.5$ & $<0.1$ & 148 & $<50$ & 0.06 & $<0.2$ & 0.2 & 0.9 & $<0.01$ & 0.4 & 0.6 & 4.42 & 24 \\
\hline 8 & $<0.5$ & $<0.1$ & 176 & $<50$ & $<0.05$ & $<0.2$ & 0.4 & 0.7 & $<0.01$ & 0.4 & 0.6 & 4.38 & 24 \\
\hline 9 & $<0.5$ & $<0.1$ & 195 & $<50$ & 0.07 & $<0.2$ & 0.3 & 1.3 & $<0.01$ & 0.4 & 0.5 & 4.42 & 24 \\
\hline \multicolumn{14}{|c|}{ Sample A97D16Z-solid:liquid $=1: 4000$} \\
\hline 1 & 5.8 & 10.0 & 200 & 72 & 3.4 & 10.7 & 1.5 & 2.5 & 0.02 & 5.1 & 5.4 & 3.75 & 24 \\
\hline 2 & 0.5 & $<0.1$ & 170 & $<50$ & 0.1 & $<0.2$ & 0.2 & 0.9 & 0.01 & 1.3 & 2.1 & 4.09 & 24 \\
\hline 3 & $<0.5$ & 1.0 & 201 & $<50$ & 0.1 & $<0.2$ & 0.2 & 1.6 & 0.01 & 1.4 & 2.1 & 4.04 & 48 \\
\hline 4 & $<0.5$ & $<0.1$ & 198 & $<50$ & $<0.5$ & $<0.2$ & 0.2 & 1.5 & 0.02 & 0.8 & 1.3 & 4.19 & 24 \\
\hline 5 & $<0.5$ & $<0.1$ & 167 & $<50$ & 0.6 & $<0.2$ & 0.4 & $1.1<$ & $<0.01$ & 0.4 & 0.8 & 4.34 & 24 \\
\hline 6 & $<0.5$ & $<0.1$ & 235 & $<50$ & 0.6 & $<0.2$ & 0.1 & $1.5<$ & $<0.01$ & 0.3 & 0.5 & 4.48 & 24 \\
\hline 7 & $<0.5$ & $<0.1$ & 196 & $<50$ & $<0.5$ & $<0.2$ & 0.3 & 0.6 & $<0.01$ & 0.3 & 0.5 & 4.48 & 24 \\
\hline 8 & $<0.5$ & $<0.1$ & 203 & $<50$ & $<0.5$ & $<0.2$ & 0.1 & 1.0 & $<0.01$ & 0.3 & 0.5 & 4.46 & 24 \\
\hline 9 & $<0.5$ & $<0.1$ & 212 & $<50$ & $<0.5$ & $<0.2$ & 0.2 & $0.9<$ & $<0.01$ & $<0.1$ & 0.9 & 5.16 & 24 \\
\hline
\end{tabular}


Appendix III. Concentrations of sulfate and hydrogen ion in leachates of X. Y. and Z on a per gram basis.

\begin{tabular}{cr}
$\begin{array}{l}\text { millimoles } \\
\text { SO4/g }\end{array}$ & \multicolumn{1}{l}{$\begin{array}{l}\text { millimoles } \\
\text { H+/g }\end{array}$} \\
0.214 & \\
0.069 & 0.62 \\
0.077 & 0.27 \\
0.05 & 0.28 \\
0.0354 & 0.176 \\
0.0271 & 0.142 \\
0.0208 & 0.126 \\
0.0188 & 0.116 \\
0.0167 & 0.108 \\
& 0.1 \\
Y LEACHATES & \\
0.2125 & 0.75 \\
0.0687 & 0.27 \\
0.0781 & 0.27 \\
0.05 & 0.222 \\
0.05 & 0.15 \\
0.0188 & 0.108 \\
0.0188 & 0.102 \\
0.0188 & 0.114 \\
0.0156 & 0.102 \\
& \\
0.225 & \\
0.0875 & 0.76 \\
0.0875 & 0.296 \\
0.0542 & 0.328 \\
0.0333 & 0.256 \\
0.0208 & 0.168 \\
0.0208 & 0.148 \\
0.0208 & 0.136 \\
& 0.156
\end{tabular}

